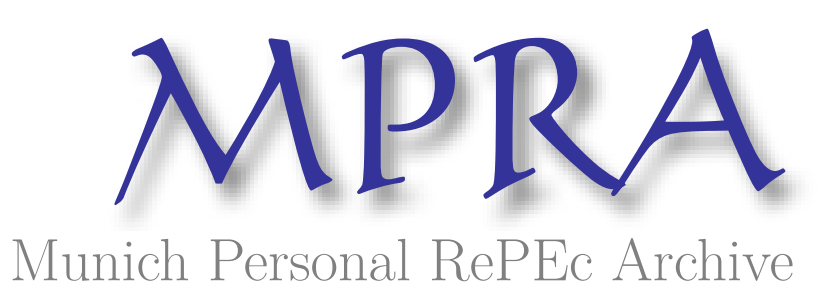

\title{
Meaning and measurement of national accounts statistics
}

Bos, Frits

February 2013

Online at https://mpra.ub.uni-muenchen.de/44970/

MPRA Paper No. 44970, posted 12 Mar 2013 14:11 UTC 
EAGLE ECONOMICS \& STATISTICS

Lindenlaan 24, 2651 TK Berkel en Rodenrijs

Netherlands

eagle_econstat@kpnmail.nl

\section{Meaning and measurement of national accounts statistics}

\section{Frits Bos}

Paper discussed online at the World Economics Association's Conference on the Political Economy of Economic Metrics, 28 January-25 February 2013 


\section{Abstract}

This paper provides an introductory overview of the meaning and measurement of national accounts statistics. Attention is paid to the various uses of national accounts, the role of the international guidelines, the relationship with economic theoretic and administrative concepts and the measurement practice. The latter is also compared with compiling other statistics, econometric modelling and a barometer: what are the similarities and differences?

Key words: Uses of national accounts, history of national accounting and macro-economic statistics, relevance and reliability of the national accounts, Petty, King, Vauban, Quesnay, Keynes, Clark, Kuznets, Leontief, Tinbergen, Hicks, Stone, Meade, guidelines on national accounting, European unification, macro-economic modeling and forecasting, GDP, economic growth and welfare, measurement in economics

JEL code: B00, C82, D70, E01, E60, O10, O20, O47, O57, Q56. 


\section{Introduction}

All over the world national accounts statistics have made the size, composition and development of national economies and their major components visible. As a consequence, they can be monitored, analyzed, forecasted en used for decision-making. Key-indicators like GDP-volume growth, national income per capita and government deficit and debt as a percentage of GDP, play a central role in managing and analyzing economies all over the world. Many decisions, income and expenditure are directly influenced by national accounts statistics. But what is their exact meaning and how reliable is their measurement? How fair and relevant are the underlying concepts? What are the major differences with concepts used in economic theory or for administrative purposes? How comparable and reliable are the national accounts statistics of the various countries?

Despite the worldwide use of the national accounts, the answers to these questions are not commonly known. This applies to policy-makers, economic journalists, economic researchers and national accountants alike.

Among economic researchers there is a worldwide illiteracy in national accounting. This is quite different from the situation some decades ago. Since the 1930's, during about half a century, national accounting was at the forefront of economic research. This is reflected by the Nobel-prizes. Three Nobel-prizes have been awarded to economists mainly working on the national accounts (Kuznets, Leontief and Stone). Many other Nobel-laureates have significantly contributed to the development of the national accounts (e.g. Hicks, Meade and Frisch) or were major users of national accounts (e.g. Tinbergen, Klein, Friedman, Prescott and Kydland). Knowledge at universities of national accounting and understanding of the merits and limitations of national accounts statistics was therefore relatively well developed. However, more and more the existence of national accounts statistics has been taken for granted, the frontiers of economic research have shifted (e.g. to micro-economic research), national accounts became more complex and a profession separate from economic theory and econometric modelling. As a consequence the academic return on investing in knowledge of national accounting rapidly declined. For more than a decade, national accounting was even dropped as a separate topic of research on the list of the Journal of Economic Literature; only some years ago, it has been reintroduced.

For the analysis of economic statistics solid knowledge of the merits and limitations of their concepts and measurement is indispensable. According to Schumpeter (1945, p. 14): 
"We need statistics not only for explaining things, but also in order to know precisely what there is to explain. ... It is impossible to understand statistical figures without understanding how they have been compiled. It is equally impossible to extract information from them or to understand the information that specialists extract for the rest of us without understanding the methods by which this is done- and the epistemological backgrounds of these methods. Thus, an adequate command of modern statistical methods is a necessary (but not a sufficient) condition for preventing the modern economist from producing nonsense".

Also for good macro-economic policy and analysis, knowledge of national accounting is important but often lacking. According to Mankiw (2006, p. 30):

"While the early macroeconomists were engineers, the macroeconomists of the past several decades have been more interested in developing analytic tools and establishing theoretical principles. These tools and principles, however, have been slow to find their way into applications. As the field of macroeconomics has evolved, one recurrent theme is the interaction -sometimes productive and sometimes not- between the scientists and the engineers. The substantial disconnect between the science and engineering of macroeconomics should be a humbling fact for all of us working in the field. ... Just as the world needs both scientists and engineers, it needs macroeconomists of both mindsets."

The widespread illiteracy in national accounting among researchers should therefore be regarded as a threat to economics as an empirical and policy relevant science.

Economic researchers and their textbooks educate those that become later users of national accounts statistics, e.g. policy-makers, journalists, financial analysts and teachers in economics. A common complaint of these courses is the treatment of national accounting: national accounts statistics are important for their jobs, but have been insufficiently discussed during their courses in economics.

The same applies to administrative concepts, like those in business accounts, government accounts and concepts of taxable business and household income. Understanding these administrative concepts and their relationship with the national accounts and economic theory is very important for a proper use of national accounts statistics and for meaningful applied economic analysis. For example, financial markets and managers of corporations are 
likely to react on annual or quarterly profits before and after tax and much less on theoretically superior notions of expected net return based on a proper valuation of risk and uncertainty. Similarly, governments are affected by figures on government deficit and debt (and much less on a complete balance sheet of the government or sophisticated calculations of sustainable public finance) and the supply of labour is influenced by (marginal changes in) administrative concepts of (taxable) income. Such important administrative concepts may also be improved by the input from economic theory.

Also national accountants often do not speak their own language fluently: many have problems in understanding the logic, merits and limitations of their own concepts. In their daily work, national accountants generally focus on compiling statistics. Compiling them timely and in an efficient and reliable way is already a very complicated and a challenging task. Explaining the concepts to data users and investigating their relevance for various types of data needs is usually not a priority. They are also often not fully aware of the many different and specific ways in which national accounts concepts and statistics are actually employed by the widely different types of users, e.g. researchers and politicians. As a consequence, giving adequate guidance to such data users becomes then also quite difficult.

The scope and variety of national accounts statistics published world wide is drastically expanding and the concepts become much more complex and subtle. This increasing complexity partly reflects a growing complexity in economic reality, e.g. all kinds of new financial instruments and mixes of public and private insurance and even more global production processes and financial markets. The increasing scope, variety and complexity of national accounts make investing in national accounting knowledge even much more time consuming and demanding.

This paper serves to help reducing this knowledge gap and stimulate investments in national accounting knowledge and national accounts statistics. It provides an introductory overview of the meaning and measurement of national accounts statistics. Attention is paid to the various uses of national accounts, the role of the international guidelines, the relationship with economic theoretic and administrative concepts and the measurement practice. The latter is also compared with compiling other statistics and econometric modelling: to what extent are these similar or (fundamentally) different?

Section 2 provides a short history of national accounting. It serves as a first introduction to the uses and meaning of national accounting and clarifies also the role of the international guidelines. 
Starting from some simple tables and graphs, section 3 explains and discusses the universal national accounting framework and its key-aggregates. This includes a discussion of the relationship with economic theoretic and administrative concepts.

Measurement practice in terms of data sources and compilation methods is the topic of section 4. Conclusions are drawn in section 5. 


\section{A concise history of national accounting}

The history of national accounting ${ }^{1}$ can be broken down into three periods:

- early estimates (1660-1930);

- revolutionary decades (1930-1950)

- era of the international guidelines (1950-present).

\section{The early estimates}

The estimates of national income and wealth by Petty, King and Davenant in England and Boisguillebert and Vauban in France started 'Political Arithmetick' (see table 2.1). All early estimates of national income were practical and directed at concrete policy issues, e.g. could England finance the war with Holland? This was a common feature of national income studies up to the 1920's. They were therefore not only the start of measuring national economies, but implied also the start of quantitative economic policy analysis. The policy issues addressed were national economic power and performance, poverty, unfair and inefficient taxation and sustainability of public finance. Often, several of these issues were discussed and the national accounts approach was essential for demonstrating that the various issues were intimately linked.

War, substantial economic decline and wide-spread poverty were circumstances that stimulated the early estimates. Also the availability of census data or income tax data was important; this partly explains the dominant role of the English estimates.

The ruling class was often not very happy with the national income estimates and the accommodating proposals for reform. Early national accountants were sometimes exiled (e.g. Radishchev in Russia) or fell into disgrace (e.g. Vauban in France); others may have feared the consequences of publishing their work and left it therefore unpublished. However, in the twentieth century -probably linked to advancements made in democracy- estimating national income became gradually to be perceived as a task of the government. In many countries, also private institutions took the responsibility of regularly compiling national accounts statistics and producing national income studies.

\footnotetext{
1 This section is based on Bos (2008), Bos (2009a, chapters 2, 3 and 4) and Bos (2011). The best source on early national income estimates is still Studenski (1958); about early English estimates, see also Stone (1997). For more recent developments, see e.g. Vanoli (2005) and Kenessey (1994). Maddison (2003 and 2005) provides a historical overview mainly restricted to the measurement of economic growth.
} 


\begin{tabular}{|c|c|}
\hline Table 2.1 & Major events in the early estimates of national accounting \\
\hline Year & Event \\
\hline $1660-1710$ & $\begin{array}{l}\text { First national income estimates; in England by Petty, King and Davenant; } \\
\text { in France by Boisguillebert and Vauban }\end{array}$ \\
\hline 1707 & First index-numbers by Fleetwood \\
\hline 1760 & $\begin{array}{l}\text { Tableau économique by Quesnay: economic accounts used as } \\
\text { a primitive growth and general equilibrium model; precursor of input-output tables }\end{array}$ \\
\hline 1770 & The concept of value added invented by Young \\
\hline $1790-1800$ & First national income estimates in Russia \\
\hline $1798-1804$ & First national income estimates in the Netherlands \\
\hline 1805 & First national income estimate in Germany \\
\hline 1823 & First national income estimates in constant prices by Lowe \\
\hline 1843 & First national income estimates in the USA \\
\hline 1886 & First official national income estimates by the government (Australia, Coghlan) \\
\hline $1860-1900$ & First national income estimates in Austria, Australia, India and Greece \\
\hline 1915 & $\begin{array}{l}\text { W.I. King (USA): one of the last national income estimates combined with clear } \\
\text { policy conclusions }\end{array}$ \\
\hline $1920-1930$ & $\begin{array}{l}\text { Private institutions start publishing national income studies, e.g. university } \\
\text { institutes in Sweden and Norway, USA: Brookings Institutions, NBER, National } \\
\text { Industrial Conference Board; Austria WIFO }\end{array}$ \\
\hline $1925-1940$ & $\begin{array}{l}\text { More official national income estimates, e.g. Greece, Canada, Soviet Russia, } \\
\text { Germany, Netherlands, New Zealand, USA and Turkey }\end{array}$ \\
\hline
\end{tabular}

National accounting had a brilliant start with the work by Petty and King. Since then, progress in national accounting was often slow and small and there were major cases of regress, like the production boundary used. For three quarters of a century, Smith was very influential in his argument that labourers in agriculture as well as in manufacturing, commerce and the transportation of goods were to be regarded as 'productive'. However, unlike King, he still rated "the whole civil and military personnel of government, the professions, the domestics, and others engaged in the performance of personal services and the services of dwellings" as unproductive labourers (see Studenski, 1958). Despite such unfortunate intellectual detours, at the beginning of the twentieth century, the common stock of knowledge on national accounting had already become considerable. It included for example a comprehensive production boundary treating e.g. agriculture and government services as productive, the notion of three basic ways to estimate domestic product and the concepts of value added and constant prices.

\section{Revolutionary decades}

The period 1930-1950 was a revolution in terms of the roles and uses of the national accounts, e.g. the discovery of input-output analysis, purchasing power parities and macroeconometric modelling and the Keynesian revolution in economic thinking (see table 2.2). 
Most of these new uses also reinforced each other. These uses were also closely linked to the economic circumstances: the economic crisis of the thirties, the Second World War and the need for recovery afterwards stimulated an active role of the government. National accounts statistics turned out to be very useful in such circumstances for analyzing, monitoring, forecasting, discussing and planning the national economy. These decades were also a revolution in terms of the development of national accounting concepts and compilation methods. For example, the first fully worked out and detailed national accounting system was published in 1947 (the famous annex of Stone in a UN-report).

\begin{tabular}{ll}
\hline Table 2.2 New applications and uses of the national accounts during 1930-1950 \\
& Who? \\
New application or use & Clark \\
$\begin{array}{ll}\text { Purchasing power parity: international comparison of real income } \\
\text { Systematic analysis of long term growth by using national accounts }\end{array}$ & Kuznets \\
time series & Leontief \\
Input-output analysis & Tinbergen and Frisch \\
Econometric modelling of national economies & Keynes \\
Keynesian revolution and the birth of macro-economics & Meade and Stone \\
Analysing public finance in a macro-economic framework & \\
Monetary policy linked to national income instead of gold & Meade \\
\hline Analysing balance of payments in a macro-economic framework &
\end{tabular}

\section{The era of the international guidelines}

In the third period, we are still living (1950-present). Considering the very important role of the international guidelines, it could be labelled the era of the international guidelines. Major features of this period are:

- A rapid extension of the number of countries for which official and regular national accounts statistics are available. This is accommodated by the appearance of private and public forecasts of national accounts statistics and their concepts. Decision-makers and researchers become gradually accustomed to using national accounts statistics.

- The publication of international guidelines. This was very important for accumulating and transferring of knowledge on national accounting. It was also important for harmonizing the concepts used by individual countries in compiling national accounts statistics.

- Major conceptual developments, e.g. about how to measure prices and volumes. In fact, only some years ago, detailed guidelines on measuring prices and volumes in the national accounts were published. 
- For decades, the international guidelines on national accounts statistics were partly inconsistent with the international guidelines on three specific types of macro-economic statistics: balance of payments, government finance statistics and statistics on employment and population. However, in the most recent set of international guidelines, most of these inconsistencies have been resolved.

- The development of all kinds of satellite accounts, e.g. on the environment. This implies that the national accounts is not only a tool for macro-economic management, but also becomes a tool for such specific policy areas.

- Political and economic circumstances favouring a harmonized national accounts approach in policy and analysis, e.g. globalisation, European unification, the collapse of communism in Eastern Europe and China and an important role for international organisations (IMF, World Bank, United Nations, European Union).

\begin{tabular}{ll}
\hline Table 2.3 & \multicolumn{1}{c}{ The successive guidelines on national accounting } \\
1947 & $\begin{array}{l}\text { Technical report by the UN containing recommendations; including } \\
\text { the famous annex by Stone: the first detailed and fully worked national accounting } \\
\text { system }\end{array}$ \\
$1951-1953 \quad \begin{array}{l}\text { First generation of international guidelines: OEEC guidelines of } 1951 \text { and 1952; } \\
\text { UN guideline of } 1953 \text { (SNA53); very simple tables and accounts }\end{array}$ \\
$1968-1970 \begin{array}{l}\text { Second generation of international guidelines: UN guideline of } 1968 \text { (SNA68), } \\
\text { the European guideline of } 1970 \text { (ESA70) and the Material Product System of 1969 } \\
\text { (MPS69) for communist countries }\end{array}$ \\
$1993-1995 \begin{array}{l}\text { Third generation of international guidelines: joint guideline of } 1993 \text { by the } \\
\text { international organizations (SNA1993 by UN, IMF, World Bank, OECD and EC) } \\
\text { and the European guideline of 1995 (ESA1995) }\end{array}$ \\
Fo08-2010 $\begin{array}{l}\text { Fourth generation of international guidelines: updates of the joint and European } \\
\text { guidelines(SNA2008 and ESA2010) }\end{array}$
\end{tabular}

International guidelines have been influential for many reasons. Firstly, the leading international experts of the profession have developed the systems in the international guidelines. They are therefore relatively well thought out and it is costly, time consuming and not easy to invent an alternative system. Secondly, by keeping in line with the international guidelines, national figures can be compared with figures from other countries. This is important, as international comparison is a major use of national accounting figures. Thirdly, in many countries, the national accounts have been set up by or improved with help from the international organisations issuing the guidelines (UN, OECD, EU) or with help from countries advanced in national accounting (Sweden, France). In the latter case, following the 
international guidelines is usually stimulated to the extent that the helping countries follow them. Fourthly, we mention that all countries are obliged to compile some figures on the basis of the international concepts. In the EU, due to some important administrative uses, the guidelines are even legally binding; the same applies to the statistical programme linked to these guidelines. The fifth reason is that the data submitted to the international organizations play a central role in international policy discussions and decision-making, e.g. about accession to the European Union, granting loans or paying contributions to the international organizations. To link national discussion and decision-making to this international context, the international concepts have to be used for national purposes as well.

\footnotetext{
Table 2.4 Major changes in the scope of the successive universal guidelines

SNA1953 Simple set of tables and accounts in current prices, focus on some key-aggregates

SNA1968 Extended accounting system, including input-output tables, general principles on prices and volumes and financial accounts

SNA1993 Inclusion of balance sheets, employment and purchasing power parities More detailed accounting structure (more accounts, more sub-sectors and detailed supply and use tables)

Separate chapters on satellite accounts and flexible adjustments for national circumstances

Detailed discussion of general principles on prices and volumes (e.g. chaining and index formulae)

SNA2008 More detailed discussions of many topics, e.g. government accounts, the informal sector and capital services (important for productivity measurement) But no detailed discussion of price and volumes by industry/product and no separate chapters on quarterly national accounts and regional accounts (unlike ESA95 and its forthcoming update)
}

The international guidelines are very successful in standardising the concepts and classifications used in compiling national accounts figures. The guidelines achieved that all over the world official figures came to be based on uniform notions of the production boundary, asset boundary, the distinction between intermediate and final consumption, etc. 
In the late sixties and the beginning of the seventies, national income was frequently criticised for not being a welfare measure ${ }^{2}$. However, the authors of the international guidelines did not intend to provide a measure of economic welfare. For example, Jaszi even regards as one of his principal contributions to have resisted successfully to "the will-o'-thewisp of forging national output into a measure of economic welfare. I was a minority of one in a company that included such mental giants as Simon Kuznets and John Hicks, and at one point I had to defy a forceful Secretary of Commerce who had instructed the BEA [Bureau of Economic Analysis of the USA] to prepare a measure of welfare" 3 . According to Okun (1971), "[the] beauty of ... present practice is that no sensible person could seriously mistake the GNP for [a measure of total social welfare] ... Producing a summary measure of social welfare is a job for a philosopher-king". Also Denison (1971) stressed some fundamental problems for a welfare measure: "relations between environmental conditions and welfare are rarely linear, and nonlinear relationships are hard to establish. A little air pollution is harmless, more an annoyance, a great deal is lethal".

In 1972, Nordhaus and Tobin illustrated in an impressive way what accounting aimed at measuring welfare would imply. They calculated a Measure of Economic Welfare (MEW) by modifying traditional national income figures in several respects. For example, they deducted an estimated value of the disamenities of urbanisation and they added tentative estimates for the value of unpaid household services. Since then, many measures similar to MEW have been calculated (see Eisner, 1988). Frequently, these measures were presented as part of extended or total accounts. Measuring the contribution of economic activity to welfare is only one of the reasons for drawing up such accounts. Some other motives are to obtain: "more inclusive and relevant measures of capital formation and other factors in economic growth, and better and/or additional data to fit concepts of consumption, investment, and production relevant to economic theory and structural econometric relations" (Eisner, 1988, p. 1612).

The increased use of social indicators like the Human Development Index (UNDP, 1991 ) is a somewhat related development. In these social indicators, national income (per capita) is only one of the variables, other variables being e.g. infant mortality, life expectancy

\footnotetext{
2 For example, Mishan (1969). An example of an earlier critique is Margolis (1952). For an overview of major studies stressing the limitations of GDP as a proxy of welfare, see van den Bergh (2008).

3 Jaszi (1986), p. 411. A similar opinion is expressed by Stone, 1974, and by Stone, 1986, p. 457.
} 
and adult literacy rates. In contrast to measures like MEW and National Income, social indicators are not measures in money terms; they serve solely as indexes.

Also several partial approaches have been developed. Such partial approaches start from standard national accounting concepts and statistics and introduce then modifications stressing one specific issue or perspective, e.g. unpaid household services and the environment. Due to the development of satellite accounts, such information can now by linked systematically to the standard national accounts and its key-aggregates.

\begin{tabular}{|c|c|}
\hline \multicolumn{2}{|c|}{ Use of national accounts statistics for European policy } \\
\hline Policy area & Which national accounts statistic? \\
\hline Monetary policy and public finance & Government deficit and debt as a percentage of GDP \\
\hline & $\begin{array}{l}\text { Financial accounts showing e.g. the size of new mortgages } \\
\text { and loans by corporations }\end{array}$ \\
\hline $\begin{array}{l}\text { Productivity and growth policy } \\
\text { (Lisbon agenda) }\end{array}$ & $\begin{array}{l}\text { Economic growth, expenditure on Research and Development } \\
\text { as a percentage of GDP, EU-KLEMS }\end{array}$ \\
\hline Social policy & $\begin{array}{l}\text { Social protection statistics closely linked to national accounts } \\
\text { concepts }\end{array}$ \\
\hline Regional policy & Regional product per capita is yardstick for granting regional funds \\
\hline Agricultural policy & $\begin{array}{l}\text { Agricultural accounts showing also the development of farmer } \\
\text { income }\end{array}$ \\
\hline Development aid & Low domestic product per capita is a yardstick for granting aid \\
\hline Defense policy & Expenditure on defense as a percentage of GDP \\
\hline Maximum total expenditure by EC & Percentage of GNI (about $1 \%$ ) \\
\hline Member states contribution & $\begin{array}{l}\text { Percentage of GNI (but some other EC-own resources exist, e.g. } \\
\text { import duties) }\end{array}$ \\
\hline
\end{tabular}

The ongoing European unification is revolutionising European national accounting. National accounts figures, like GNP, government deficit and GDP volume growth have been selected to play a special role in monitoring and managing the European unification (see also table 2.5). This role in European policy has also drastically increased the importance of national accounts statistics in national policy. In discussing and deciding on the national budget, national accounts statistics on the government deficit have become the central figures in all EU-countries. They have often taken over this role from specifically nationally defined concepts. The Member States and the European Commission have been aware that the national accounts statistics did not suffice for such usage. They have therefore launched an ambitious program for improving the quality and comparability of present national accounts figures and for drastically extending the set of national accounts statistics that are available for all EU-Member States.

From a universal perspective, these European developments are in two respects important. Firstly, the development of jurisprudence on the interpretation and application of 
the international guidelines is a totally new development for the national accounts. Secondly, the European experience gives a concrete example of how the quality and comparability of national accounts statistics can be improved, e.g. by auditing ${ }^{4}$, issuing guidelines on inputs, official requirements for compiling and publishing an extensive set of national accounts statistics and by more specific guidelines. Some of this extra specification is also very useful for countries outside Europe, e.g. with respect to the very important distinction between market and non-market. As a consequence, concepts like value added, Domestic Product and the sector government are not clearly defined in the universal guidelines.

Under the influence of the international guidelines and the international organisations, national accounts statistics are now available for all countries. For most countries, they have also gradually extended in scope and detail. Nevertheless, still enormous differences in scope, detail, quality and frequency exist between the national accounts statistics published by countries. This applies even to a rather a homogeneous block of countries, like the EU.

For example, since the fifties countries like Norway, Denmark, the Netherlands and France publish annually input-output tables. Input-output tables were incorporated for the first time in the international guidelines in the SNA68 and ESA70. However, even now, several decades later, only a few more countries publish annually input-output tables. For a somewhat larger group incidental but usually rather outdated input-output tables exist. This applies e.g. to the USA. A similar story can be told for the detailed sector accounts proposed by the SNA68, the ESA70 and the most recent international guidelines. Even now, a great majority of the countries in the world only apply rather simple accounting systems of the SNA53-style.

Substantial differences in country practices exist also with respect to specific national accounts statistics, like regional accounts, quarterly accounts, satellites and balance sheets. In some countries, all of them are regularly published (e.g. in the Netherlands, France and Canada). In a somewhat larger group, some of them are regularly published, while in most countries hardly any data are regularly published on any of these topics.

Our remarks with respect to the input-output tables and the sector accounts reveal that most of the international guidelines have been much more ambitious and encompassing than

\footnotetext{
${ }^{4}$ For some EU-countries, this resulted in upwards revisions of official Domestic product and National income statistics of 10 to $20 \%$ !
} 
the national accounting practice of their time. This partly reflects their role as a pedagogical device and innovative instrument ${ }^{5}$.

However, in the case of the USA it may also partly reflect a fundamentally different view on the role and design of the national accounts. In line with USA national accounts practice, two quotes from American economists stress the importance of a relatively simple set of accounts and criticize the complexity and cost-inefficiency of universal accounting framework:

"These ... accounts are designed to answer "Who does What by means of What for What purpose with Whom in exchange for What with What changes in stocks?" Given this level of complexity, there is a distinct danger that when the revised SNA is actually put in place, it, like the Hubble telescope, may not be successful in bringing into focus a clear view of what it was designed to examine. Only professional national accountants will be able to fathom the national accounts. Furthermore, the establishment of such an elaborate system as the standard to be adopted by national and international statistical offices may result in the SNA becoming a statistical behemoth independent of its creators and with an illogic of its own-not unlike a Frankenstein monster. One of the major virtues of national accounting systems used by many countries is that they do provide a relatively simple macroeconomic overview of the economic system" (Ruggles, 1990, p. 419).

\footnotetext{
${ }^{5}$ It also reflects the totally different amounts of resources in countries available for statistics in general, and for national accounts in particular.
} 


\section{The universal accounting model explained by some simple tables ${ }^{6}$}

Starting from some simple tables, this section provides a brief and stylised overview of the national accounting framework in the international guidelines. These tables illustrate the major bookkeeping identities in this framework and the major uses of national accounts statistics.

Table 3.1 Three different approaches to GDP

\begin{tabular}{|l|r|}
\hline & 2010 \\
\hline Gross domestic product & 1000 \\
\hline Production approach & 1500 \\
Output & 500 \\
Intermediate consumption (minus) & \\
\hline Income approach & 800 \\
Compensation of employees & 200 \\
Gross operating surplus & \\
\hline Expenditure approach & 850 \\
Final consumption expenditure & 700 \\
$\quad$ households & 150 \\
government & 200 \\
Capital formation & 250 \\
Exports & 300 \\
Imports (minus) & \\
\hline Supply of goods and services & 1800 \\
Output & 1500 \\
$\quad$ Imports & 300 \\
Use of goods and services & 1800 \\
Intermediate consumption & 500 \\
Final consumption expenditure & 850 \\
Capital formation & 200 \\
Exports & 250 \\
\hline
\end{tabular}

Table 3.1 shows Gross Domestic Product broken down according to three basic approaches: the production approach, the income approach and the expenditure approach. The production approach reveals that Gross Domestic Product is a concept of (gross) value added that can be obtained by deducting intermediate consumption from output. The income approach shows that (gross) value added and Gross Domestic product consist of the sum of compensation of employees and gross operating surplus. The production approach and the income approach reflect the notion of production functions and macro-economic growth models in terms of

\footnotetext{
${ }^{6}$ For a much more extended discussion on the basis of a much more sophisticated set of tables, see Bos (2009a).
} 
factors of production. The expenditure approach is equal to the Keynesian macro-economic expenditure identity $(\mathrm{Y}=\mathrm{C}+\mathrm{I}+\mathrm{O}+\mathrm{E}-\mathrm{M})$. Information on the total supply and use of goods and services is hidden in the production approach and expenditure approach. At the bottom of the table, this information is extracted and it is demonstrated that here also the identity of total supply equal to total use of goods and services applies. In supply and use tables, this identity is broken down by product, e.g. the supply of oil should be equal to the use of oil.

Table 3.1 illustrates that Gross Domestic Product is not an isolated aggregate, but part of an accounting system. Changing the concept of Gross Domestic Product, e.g. by changing the production boundary, has therefore direct consequences for the definitions of the other concepts in the identities. This consistency is essential for proper economic analysis, e.g. to analyse GDP in terms of Keynesian macro-economic expenditure categories. This consistency is also important for compilation purposes, e.g. for estimating some variables as a residual of the estimates for the other variables.

For a proper interpretation of GDP statistics, it is important to be aware of the universal definitions of the underlying concepts. For example, production includes:

- Production of individual and collective services by government; this applies even to building up a massive police and defense for waging war and suppressing the population.

- Own-account production of housing services by owner-occupiers;

- Production of goods for own final consumption, e.g. of agricultural products;

- Own-account construction, including that by households;

- Production of services by paid domestic staff;

- Breeding of fish in fish farms;

- Production forbidden by law, as long as all units involved in the transaction enter into it voluntarily;

- Production from which the revenues are not declared in full to the fiscal authorities, e.g. clandestine production of textiles.

However, it excludes e.g.

- Domestic and personal services produced and consumed within the same household, e.g. cleaning, the preparation of meals or the care of young, sick or elderly people;

- Volunteer services that do not lead to the production of goods, e.g. care-taking and cleaning without payment for people from other households; 
- Natural breeding of fish in open seas.

The valuation of production is not straightforward, e.g.

- According to the universal definitions, the value of output excludes holding gains and holding losses, e.g. on selling equity and dwellings. In business accounts and taxable profits realised holding gains are often included. As a consequence, national accounts statistics on operating surplus are in this respect fundamentally different from the counterpart concepts in business accounts and business income tax.

- Output is to be valued at market prices. However, for some types of production, like the services of owner-occupied dwellings or government output, such information is not readily available. For services of owner-occupied dwellings, the market rental rates of similar dwellings rented out are to be used. For government services, output is to be valued as the sum of the various production costs, like compensation of employees, intermediate consumption and capital consumption.

In order to calculate Gross Domestic product, intermediate consumption is to be deducted. However, from a welfare point of view, some major items should also be deducted, e.g. exhaustion of natural resources like oil and forests, or the private costs to travel to work.

\section{Graph 3.1. GDP per capita for a range of countries.}

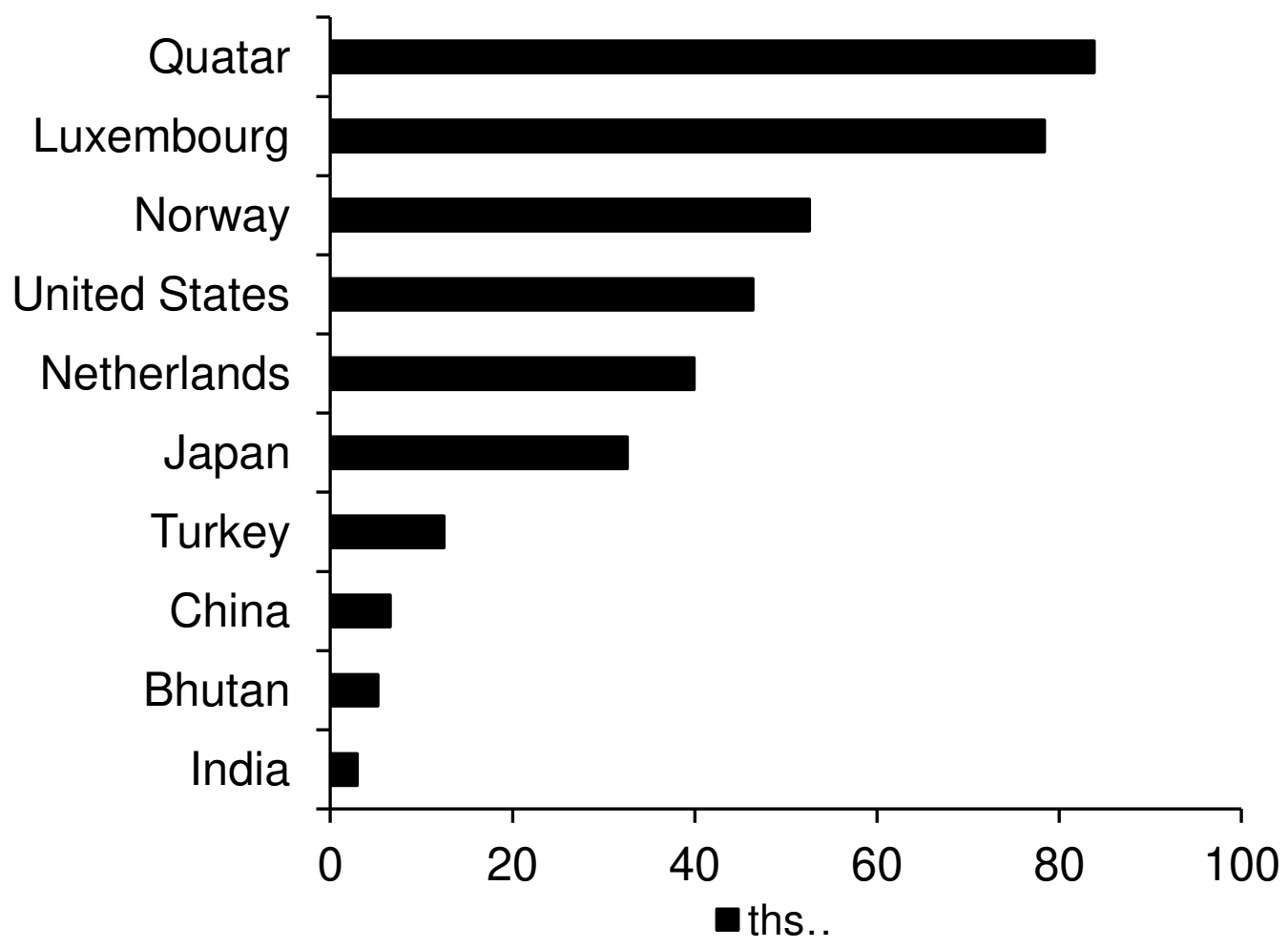


Dividing Gross Domestic Product by the number of inhabitants results into GDP per capita. This is clearly not a measure of welfare, as it ignores e.g..g. Domestic and personal services produced and consumed within the same household, changes in leisure time, amenities and disadvantages of urban life and inequalities in the distribution of income over persons. GDP per capita should therefore be regarded as a simple yardstick of average material welfare. To make international comparisons of purchasing power, GDP per capita figures should be translated in a common currency. Using the exchange rates at a specific moment in time can be very misleading. For this purpose, purchasing power parities have been developed. A very simple yardstick of the differences in prices is the price of a McDonald's hamburger, i.e. a uniform and homogeneous product which is available in nearly all countries. Similarly, the official purchasing power parities are based on a much wider package of goods and services. Graph 3.1 illustrates how such GDP per capita figures corrected can be used for international comparison of average purchasing power.

Table 3.2 GDP and employment broken down by industry

\begin{tabular}{|l|r|r|r|}
\hline & $\begin{array}{r}2010 \\
\text { values } \\
\text { current } \\
\text { prices }\end{array}$ & $\begin{array}{l}\text { l } 2010 \\
\text { employ- } \\
\text { ment }\end{array}$ & $\begin{array}{l}\text { value per } \\
\text { employed }\end{array}$ \\
\hline Gross domestic product & 1000 & 17000 & 0,06 \\
agriculture & 500 & 10000 & 0,05 \\
manufacturing & 400 & 6000 & 0,07 \\
government & 100 & 1000 & 0,10 \\
\hline Production approach & 1500 & 17000 & 0,09 \\
Output & 700 & 10000 & 0,07 \\
agriculture & 650 & 6000 & 0,11 \\
manufacturing & 150 & 1000 & 0,15 \\
government & 500 & 17000 & 0,03 \\
Intermediate consumption (minus) & 200 & 10000 & 0,02 \\
agriculture & 250 & 6000 & 0,04 \\
manufacturing & 50 & 1000 & 0,05 \\
government & & & \\
\hline Income approach & 800 & & \\
Compensation of employees & 250 & 4000 & 0,06 \\
agriculture & 300 & 6000 & 0,05 \\
manufacturing & 100 & 1000 & 0,10 \\
government & 200 & & \\
Gross operating surplus/mixed income & 250 & 6000 & 0,04 \\
agriculture & 100 & & \\
manufacturing & 0 & & \\
government & & & \\
\hline
\end{tabular}


Table 3.2 shows how Gross Domestic Product and the decomposition via the production and income approach can be broken down by industry. The table also shows how such information could be linked to employment figures. Such a linkage is useful for analysis and for compilation purposes, e.g. by estimating total compensation of employees for an industry by multiplying the number of (full-time equivalent) employees by an estimate of the average wage rate. The number of employees may also be further broken down by gender, by age or education. Also all kind of other information can be broken down by industry and linked in this way to output, value added and employment, e.g. pollution by industry or energy use by industry.

Table 3.3 Decomposition of GDP into price and volume changes

\begin{tabular}{|l|r|r|r|r|r|}
\hline & $\begin{array}{c}2010 \\
\text { current } \\
\text { prices }\end{array}$ & $\begin{array}{c}2011 \\
\text { volume } \\
\text { change }\end{array}$ & $\begin{array}{c}2011 \\
\text { prices } \\
2010\end{array}$ & $\begin{array}{c}2011 \\
\text { price } \\
\text { change }\end{array}$ & $\begin{array}{c}2011 \\
\text { current } \\
\text { prices }\end{array}$ \\
\hline Gross domestic product & 1000 & 2 & 1020 & 4 & 1061 \\
Output & 1500 & 2,5 & 1538 & 5 & 1614 \\
Intermediate consumption (minus) & 500 & 3,5 & 518 & 7 & 554 \\
Final consumption expenditure & 850 & 4 & 884 & 2 & 903 \\
$\quad$ households & 700 & 3,5 & 725 & 2 & 737 \\
$\quad$ government & 150 & 6 & 159 & 4 & 165 \\
Capital formation & 200 & 2 & 204 & 10 & 224 \\
Exports & 250 & 5 & 263 & 3 & 270 \\
Imports (minus) & 300 & 10 & 330 & 2 & 337 \\
\hline
\end{tabular}

Table 3.3 shows how GDP in current prices in two successive years can be decomposed into volume and prices changes. Multiplying GDP 2010 in current prices by the volume change in 2011, results into GDP 2011 in prices 2010. The latter could also be obtained by dividing GDP of 2011 in current prices by the price change in 2011. For compilation purposes this implies that when estimates of GDP in current prices of 2010 and 2011 are available, an estimate of volume change implies that an estimate of price change can be obtained as a residual and vice versa. Such decomposition can also be done for the breakdown for the production and expenditure approach; in supply and use tables a further disaggregation by product can be shown. Note also that the identity of GDP via the production and expenditure approach do not only hold in current prices but also when expressed in prices of the previous year. 
For analyses of GDP volume growth over time, it is often useful to make a simple decomposition on the basis of information on population growth, employment growth and growth of the potential labour force, i.e. the population between 18 years and 65 years (or any other retirement age). To this end (see table 3.4), as a first step, GDP volume growth can be divided by population growth and, as a residual, GDP volume growth per capita results. As second step the employment growth can be expressed per capita, i.e. divided by population growth. As a third step, GDP volume growth per capita can be divided by employment growth per capita; this results, as a residual, in (labour) productivity growth. The purely demographic change in the labour force can be estimated on the basis of the volume change of the potential labour force. By expressing this per capita, the residual of employment growth per capita can be labelled other reasons for employment growth per capita.

Table 3.4 Decomposition of GDP volume growth

\begin{tabular}{|l|r|}
\hline & 2011 \\
\hline GDP volume growth & 2 \\
population growth & 0,5 \\
GDP volume growth per capita & 1,5 \\
employment growth per capita & -2 \\
due to demography & -4 \\
other reasons & 2 \\
productivity growth & 3,5 \\
\hline
\end{tabular}

Table 3.5 Balance sheets by institutional sector

\begin{tabular}{|c|c|c|c|c|c|c|c|}
\hline & & $\begin{array}{c}\text { Corpo- } \\
\text { rations } \\
1\end{array}$ & $\begin{array}{l}\text { Govern- } \\
\text { ment } \\
2\end{array}$ & $\begin{array}{l}\text { House- } \\
\text { holds } \\
3\end{array}$ & $\begin{array}{c}\text { National } \\
\text { economy } \\
4\end{array}$ & $\begin{array}{l}\text { Rest of } \\
\text { the } \\
\text { World } \\
5\end{array}$ & $\begin{array}{c}\text { Total } \\
6\end{array}$ \\
\hline \multirow{3}{*}{$A$} & Opening balance sheet (end 2010) & & & & & & \\
\hline & Non-financial assets & 600 & 300 & 900 & 1800 & & \\
\hline & Financial assets & 500 & 50 & 250 & 800 & 500 & 1300 \\
\hline \multirow[t]{2}{*}{ L } & Liabilities & 300 & 800 & 150 & 1250 & 50 & 1300 \\
\hline & Net worth & 800 & -450 & 1000 & 1350 & 450 & \\
\hline \multirow{3}{*}{$A$} & Changes in balance sheet (2011) & & & & & & \\
\hline & Changes in non-financial assets & 150 & 50 & 300 & 500 & & \\
\hline & Changes in financial assets & 270 & 30 & 20 & 320 & 80 & 400 \\
\hline \multirow[t]{2}{*}{ L } & Changes in liabilities & 40 & 50 & 100 & 190 & 210 & 400 \\
\hline & Changes in net worth & 380 & 30 & 220 & 630 & -130 & \\
\hline \multirow{3}{*}{ A } & Closing balance sheet (end 2011) & & & & & & \\
\hline & Non-financial assets & 750 & 350 & 1200 & 2300 & & \\
\hline & Financial assets & 770 & 80 & 270 & 1120 & 580 & 1700 \\
\hline \multirow[t]{2}{*}{ L } & Liabilities & 340 & 850 & 250 & 1440 & 260 & 1700 \\
\hline & Net worth & 1180 & -420 & 1220 & 1980 & 320 & \\
\hline
\end{tabular}

$A=$ Assets, $L=$ Liabilities 
The accounts for the institutional sectors provide a complete and systematic description of a national economy in terms of a set of inter-linked account. Each of these accounts describes an economic-subprocess. The balancing items show the net result of the sub-process. All flow accounts together account for all possible changes in stocks, i.e. in non-financial assets, financial assets and liabilities.

Table 3.5 shows balance sheets for three domestic institutional sectors (corporations, government and households) and a separate sector Rest of the World for summarizing their relationship with institutional units abroad. Also in this table several accounting identities apply:

- The closing balance sheet at the end of 2011 and its assets, liabilities and net worth are equal to opening balance sheet at the end of 2010 plus the various types of changes during the year 2011. This identity reflects that the balance sheets are a doubly-entry bookkeeping system like the business accounts.

- The assets and liabilities of the national economy are the sum of the assets and liabilities of the three domestic sectors.

- The total financial assets owned by domestic units plus claims by the rest of the world on domestic units is equal to total liabilities of domestic units plus liabilities of the rest of the world to domestic units. This reflects that the balance sheet is part of a quadruply-entry bookkeeping system: the liabilities of one unit are by definition matched by the financial asset of another unit. This applies not only to financial assets and liabilities of domestic units with other (domestic or foreign) units, but also to all kinds of transactions, like buying and selling goods and services, compensation of employees or property income (see tables 3.6 and 3.7).

The liabilities and the financial and non-financial assets in the balance sheet could be brokendown by type of asset or liability. The changes in assets can also be broken-down into the type of change. For example, changes in non-financial assets can be broken-down into gross capital formation, consumption of fixed capital (minus), acquisition of other non-financial assets (e.g. land or copy-rights), other volume changes in non-financial assets (e.g. due to fire) and holding gains and losses. The breakdown by sector could also be more detailed, e.g. showing also financial corporations separately or breaking down the government into central and local government. 
Tables 3.6 and 3.7 show the flow accounts by institutional sector. Table 3.6 contains the current account and table 3.7 the accumulation account; the accumulation account is a decomposition of the changes in balance sheet account.

Table 3.6 Flow accounts by institutional sector: current account

\begin{tabular}{|c|c|c|c|c|c|c|c|}
\hline & & $\begin{array}{c}\text { Corpo- } \\
\text { rations } \\
1\end{array}$ & $\begin{array}{l}\text { Govern- } \\
\text { ment } \\
2\end{array}$ & $\begin{array}{l}\text { House- } \\
\text { holds } \\
3\end{array}$ & $\begin{array}{c}\text { National } \\
\text { economy } \\
4\end{array}$ & $\begin{array}{l}\text { Rest of } \\
\text { the } \\
\text { World } \\
\quad 5\end{array}$ & $\begin{array}{c}\text { Total } \\
6\end{array}$ \\
\hline $\begin{array}{l}\mathrm{R} \\
\mathrm{U}\end{array}$ & $\begin{array}{l}\text { Production account } \\
\text { Output (/imports) } \\
\text { Intermediate consumption (exports) } \\
\text { Gross value added }\end{array}$ & $\begin{array}{l}650 \\
250 \\
400 \\
\end{array}$ & $\begin{array}{r}150 \\
50 \\
100 \\
\end{array}$ & $\begin{array}{l}700 \\
200 \\
500 \\
\end{array}$ & $\begin{array}{r}1500 \\
500 \\
1000 \\
\end{array}$ & $\begin{array}{l}300 \\
250\end{array}$ & $\begin{array}{r}1800 \\
750\end{array}$ \\
\hline $\begin{array}{l}\mathrm{R} \\
\mathrm{U}\end{array}$ & $\begin{array}{l}\text { Generation of income account } \\
\text { Gross value added } \\
\text { Compensation of employees } \\
\text { Gross operating surplus }\end{array}$ & $\begin{array}{l}400 \\
300 \\
100 \\
\end{array}$ & $\begin{array}{l}100 \\
100\end{array}$ & $\begin{array}{l}500 \\
250 \\
250 \\
\end{array}$ & $\begin{array}{r}1000 \\
650 \\
350 \\
\end{array}$ & 25 & 675 \\
\hline U & $\begin{array}{l}\text { Allocation of primary income account } \\
\text { Gross operating surplus } \\
\text { Compensation of employees } \\
\text { Property income receivable } \\
\text { Property income payable } \\
\text { Balance of primary incomes }\end{array}$ & $\begin{array}{r}50 \\
30 \\
120 \\
\end{array}$ & $\begin{array}{r}5 \\
80 \\
-75 \\
\end{array}$ & $\begin{array}{r}250 \\
600 \\
25 \\
15 \\
860 \\
\end{array}$ & $\begin{array}{r}350 \\
600 \\
80 \\
125 \\
905 \\
\end{array}$ & \begin{tabular}{r|}
75 \\
50 \\
5
\end{tabular} & $\begin{array}{l}675 \\
130 \\
130\end{array}$ \\
\hline U & $\begin{array}{l}\text { Secondary distribution of income } \\
\text { account } \\
\text { Balance of primary incomes } \\
\text { Taxes on income } \\
\text { Taxes on income } \\
\text { Disposable income }\end{array}$ & $\begin{array}{l}120 \\
25 \\
95 \\
\end{array}$ & $\begin{array}{l}-75 \\
175 \\
100 \\
\end{array}$ & $\begin{array}{l}860 \\
155 \\
705\end{array}$ & $\begin{array}{l}905 \\
175 \\
180 \\
900\end{array}$ & $\begin{array}{l}5 \\
0\end{array}$ & $\begin{array}{l}180 \\
180\end{array}$ \\
\hline $\begin{array}{l}\mathrm{R} \\
\mathrm{U}\end{array}$ & $\begin{array}{l}\text { Use of disposable income account } \\
\text { Disposable income } \\
\text { Final consumption expenditure } \\
\text { Saving/current account of ROW }\end{array}$ & 95 & $\begin{array}{l}100 \\
150 \\
-50\end{array}$ & $\begin{array}{r}705 \\
700 \\
5\end{array}$ & $\begin{array}{r}900 \\
850 \\
50\end{array}$ & 150 & 850 \\
\hline
\end{tabular}

$\mathrm{R}=$ Resources; $\mathrm{U}=$ Uses

The flow accounts consist of different accounts (e.g. production account, generation of income account), each containing a different economic sub-process with a balancing item, which summarizing the net result of the economic process (e.g. value added, or gross operating surplus).

Net borrowing is the balancing item of the capital account. As each account starts with the balancing item of the previous account, net borrowing also serve as the balancing 
item of all resources and uses from the production account upto the capital account. Net lending is the mirror-image of net borrowing. It is the balancing item of the financial account. This implies that net lending (or net borrowing) can be estimated or interpreted in two ways: as the balancing item of all resources and uses in the current and capital account (what is the net result of all current and capital transactions?) or as the balancing item of the net acquisition of financial assets and the net incurrence of liabilities. The latter can be regarded as the way the net result of all current and capital transactions is actually financed.

Table 3.7 Flow accounts by institutional sector: accumulation account

\begin{tabular}{|c|c|c|c|c|c|c|c|}
\hline & & $\begin{array}{c}\text { Corpo- } \\
\text { rations } \\
1 \\
\end{array}$ & $\begin{array}{l}\text { Govern- } \\
\text { ment } \\
2\end{array}$ & $\begin{array}{l}\text { House- } \\
\text { holds } \\
3\end{array}$ & $\begin{array}{l}\text { National } \\
\text { economy } \\
4\end{array}$ & $\begin{array}{l}\text { Rest of } \\
\text { the } \\
\text { World } \\
\quad 5\end{array}$ & $\begin{array}{r}\text { Total } \\
6 \\
\end{array}$ \\
\hline L & $\begin{array}{l}\text { (Non-financial) capital account } \\
\text { Gross capital formation } \\
\text { Consumption of fixed capital (minus) } \\
\text { Saving/current account of ROW } \\
\text { Net borrowing }\end{array}$ & $\begin{array}{r}200 \\
-150 \\
95 \\
-45\end{array}$ & $\begin{array}{r}-50 \\
50\end{array}$ & $\begin{array}{r}5 \\
-5\end{array}$ & $\begin{array}{r}200 \\
-150 \\
50 \\
0\end{array}$ & $\begin{array}{r}150 \\
-150\end{array}$ & 200 \\
\hline $\begin{array}{l}\text { A } \\
L\end{array}$ & $\begin{array}{l}\text { Financial account } \\
\text { Net acquisition of financial assets } \\
\text { Net incurrence of liabilities } \\
\text { Net lending }\end{array}$ & $\begin{array}{r}220 \\
40 \\
45 \\
\end{array}$ & $\begin{array}{r}30 \\
50 \\
-50 \\
\end{array}$ & $\begin{array}{r}20 \\
100 \\
5 \\
\end{array}$ & $\begin{array}{r}270 \\
190 \\
0 \\
\end{array}$ & $\begin{array}{r}80 \\
160 \\
150 \\
\end{array}$ & $\begin{array}{l}350 \\
350\end{array}$ \\
\hline L & $\begin{array}{l}\text { Other changes in assets account } \\
\text { Other changes in non-financial assets } \\
\text { Other changes in financial assets } \\
\text { Other changes in liabilities } \\
\text { Net other changes in assets }\end{array}$ & $\begin{array}{r}100 \\
50 \\
150\end{array}$ & 50 & 300 & $\begin{array}{r}450 \\
450\end{array}$ & $\begin{array}{r}50 \\
-50\end{array}$ & $\begin{array}{l}50 \\
50\end{array}$ \\
\hline
\end{tabular}

$A=$ Assets, $L=$ Liabilities

The resources and uses of the government in the flow account contain a lot of double counting; this is due to inserting balancing items per economic subprocess and due to imputing as a resource a value of government output by amount of the sum of production costs (compensation of employees and intermediate consumption) in the production account, and off-setting this by imputing final consumption expenditure in the use of disposable income account. The accounts for the sector government are therefore not very useful for analysing government finance. For this important purpose, the resources and uses of the government in the flow accounts can be translated into a table showing revenue and expenditure of the government, with net lending (government deficit) as a balancing item (see table 3.8). 
Table 3.8 Government revenue, expenditure and deficit (net lending)

\begin{tabular}{|l|r|r|}
\hline & 2011 & 2011 \\
& $\begin{array}{r}\text { current } \\
\text { prices }\end{array}$ & \% GDP \\
\hline Total revenue & 180 & 18 \\
Taxes on income & 175 & 17,5 \\
Property income receivable & 5 & 0,5 \\
\hline Total expenditure & & \\
Compensation of employees & 230 & 23 \\
Intermediate consumption & 100 & 10 \\
Gross capital formation & 50 & 5 \\
Property income payable & 0 & 0 \\
\hline & 80 & 8 \\
Net lending & & -5 \\
\hline
\end{tabular}

Total expenditure by government could also by classified by function, e.g. defense, education public administration and healthcare.

This overview on the basis of a set of simple tables reveals that the accounting framework does not only provide a overview of the national economy. It contains also in an ingenious way the perspectives of several other major types of applied economic analysis, e.g. balance of payments (rest of the world account), government finance, monetary analysis, input-output analysis and international comparison of purchasing power.

\section{Economic theory and the universal national accounting model $^{7}$}

The universal national accounting model is influenced by economic theory in four respects:

1. It can be regarded as a mix of various types of applied economic theory, e.g. accountancy, government finance, balance of payments, input-output tables, index number-theory, monetary analysis and Keynesian analysis.

2. It gives a concrete and specific meaning to concepts used in economic theory, e.g. taxes, economic growth, national income, capital formation, government and government deficit.

3. Economic theory can be used for defining national accounting concepts, e.g. valuation at market prices is the preferred principle of valuation, the notion of price discrimination is used for distinguishing between prices and volumes, interest is recorded on zero-coupon bonds and net discounted value is used as a supplementary principle of valuation.

\footnotetext{
7 About the relationship between economic theory and national accounting, see Bos (1993), Bos (1995), Kendrick (1995), Bos (1997), Bos (2009a) and Bos (2011).
} 
4. Economic theory can clarify the relevance of national accounts statistics for various uses, e.g. by demonstrating that Domestic Product should not be regarded as a welfare measure. These insights from economic theory may also influence the design of the universal model. Economic theoretic concepts are designed to be meaningful for economic analysis and decision-making. They can also help to see through the complex, heterogeneous and misty administrative realities.

However, economic theoretic concepts may for various reasons also be disregarded by the national accounts, because:

- They may not be suitable for compiling regular statistics; though they may be suited for measurement as a research exercise;

- They can conflict with alternative theoretic concepts;

- They can deviate too much from administrative concepts;

- They can not be reconciled with the ex post accounting logic of national accounts statistics.

The universal national accounts' description of the national economy is closer in spirit to some economic theories (e.g. Keynesian theory, monetary analysis, input-output analysis) than to others (e.g. welfare economics and micro-economic theory on household production).

The universal national accounts can be regarded as a child of the Keynesian revolution. The introduction of a sector government, the distinction between public and private corporations and the concept of household consumption expenditure included consumer durables reflect this. The universal national accounts also seems to meet the general needs for monetary and port-folio analysis, e.g. the sector financial corporations and its subsectors, the accumulation accounts and balance sheets and the systematic links to the real part of the national economy and rest of the World. Furthermore, the universal national accounts reflect a clear meso-economic approach to the national economy and in particular to the production process.

The universal national accounts are clearly at odds with welfare economics, as they does not aim to include extended concepts of income and wealth. Similarly, fundamental differences exist with human capital theory and micro-economic theories on household income and production. The universal national accounts ignores unpaid household services, does not regard the purchase of education and consumer durables as investment, does not 
regard employees as producers of services and pays limited attention to the total supply of labour.

These biases in the universal national accounts seem to reflect the focus on staying relatively close to what can readily be observed in monetary terms, i.e. to measure what can best be measured in monetary terms. This can be regarded as a conservative bias, as it reflects to a great extent administrative realities. However, for a framework for compiling regularly statistics, this is a very natural and evident bias. Nevertheless, data users should be aware of the implications of this bias, e.g. that national income is no measure of welfare.

\section{Administrative concepts and the universal national accounting model}

The universal national accounting model is also influenced by the data sources and administrative concepts. Concepts in national accounts statistics should have a good link to those in administrative data sources, like various tax data (VAT, personal income tax, import levies), business accounts, social security records and data from supervisory boards on banking and insurance, etc. This is essential because they serve often directly or indirectly as inputs for compiling national accounts statistics. Furthermore, administrative concepts are an important part of economic reality, as they play a central role in decision-making by government, enterprises and households. Therefore, if the national accounts concepts diverge too much from these administrative concepts, they are difficult to understand, difficult too compile and are less likely to meet the data needs for economic analysis and decisionmaking.

Nevertheless, national accounting concepts usually differ in some respects from the administrative counterparts, because the latter:

- differ between countries, which hampers international compatibility;

- change over time, which hampers comparability over time;

- are usually not consistent with each other. As a consequence, administrative concepts can not be linked and aggregated meaningfully.

- are often not optimal for economic analysis and decision-making.

The universal national accounts have much in common with administrative data, like business accounts and government accounts, e.g. the presentation in terms of accounts, the use of double-entry bookkeeping, the terminology and the focus on what can be readily measured in monetary terms. Nevertheless, there are also four important differences: 
- The national accounts are much more standardised nationally, internationally and over time.

- The national accounts distinguish many more accounts and balancing items.

- The central concepts of the universal national accounts, like value added and disposable income, are rather different from the central concepts in the business accounts and government accounts.

- The concepts in the national accounts differ substantially with respect to delimitation, valuation and time of recording.

These differences reflect to a great extent two differences in purposes. The first difference pertains to the need to standardisation. Standardisation of the national accounting concepts is essential for obtaining meaningful and comparable totals. Standardisation of the business accounts and government accounts is less essential. Nevertheless, globalisation, further economic integration and rapidly developing financial capital markets have also increased the need for business accounts and government to become more standardized and comparable all over the world.

The second difference is that the purpose of the national accounts is to describe corporations and government units as part of a consistent description of the national economy; this is no purpose of the business accounts and the government accounts.

\section{The universal national accounting model as a tool for analysis and policy}

National accounts statistics serve many types of economic analyses, policy and private decision-making. From this instrumental point of view, the major merits of the universal national accounts are:

- Multi-purpose;

- Based on a set of established concepts inspired by economic principles and economic reality;

- Relatively close to what can be readily observed in monetary terms;

- Relatively close to administrative realities;

- Harmonised with concepts in statistics;

- Based on rigorous accounting logic;

- Internationally standardised.

The universal national accounts are in general well designed and well founded. They do contain systematic biases. However, these biases merely reflect the natural focus of a 
regular statistic, i.e. a focus on what can be readily measured. This applies e.g. to unpaid household services and tax expenditures. Including such more analytic elements generally increases the relevance of the universal national accounts for one specific purpose, while reducing it for most other purposes. Such concepts with substantial negative external effects for other purposes should therefore not be included in the basic concepts.

\section{The universal national accounting model as a measurement tool}

The universal national accounting model does not provide a complete picture of the national economy but a selective view. Major economic items excluded are unpaid household services, volunteer services, leisure time and tax expenditure. This reflects the focus on the part of the national economy that can be readily measured in monetary terms.

Nevertheless, even in describing this 'measurable' selection of the national economy the standard national accounts contain many transformations of the flows and stocks as they occur or can be measured directly. Types of transformation included are:

- grouping/aggregating/omitting, e.g. most economic relationships within corporations;

- imputing, e.g. services of owner-occupied dwellings or retained earnings on direct foreign investment;

- translating flows in kind into monetary terms, e.g. income in kind;

- translating cash flows into flows on a transactions basis, e.g. tax receipts;

- recording one flow twice or even more times, e.g. most of the production costs of government;

- netting, e.g. gross fixed capital formation is the net result of the purchase and sale of fixed assets;

- translation of nominal values into prices, volumes and real values, e.g. economic growth, productivity change or Domestic Product per capita corrected for differences in purchasing power.

These transformations translate the complex and very heterogeneous economic reality in a meaningful and comprehensible description of the national economy. This is a major merit of the universal national accounting model and it is essential for the relevance of national accounts statistics. The model is built on many choices (conventions) on how to label flows, stocks and the actors of the national economy. This applies e.g. to standard national accounts concepts of output (e.g. compensation of employees is not output produced by the employee but primary income), capital formation (e.g. the purchase of software is capital formation and 
not intermediate consumption), income (e.g. national income excludes holding gains), government (e.g. excluding the Central Bank) and prices and volumes (e.g. quality-change should be regarded as a volume-change). Different choices would have resulted in a different picture of the real world. 


\section{Measurement practices}

\section{The operational model, data sources and the compilation process}

The universal national accounting model can not be estimated directly. It should first be translated into an operational model for a specific country during a specific period of time. This involves interpretation of the universal model in view of the national economy and further specification of the concepts, detail and scope. The operational model decides to a substantial extent what is actually measured. Differences in national operational models are therefore a serious threat to international comparability. This applies in particular to the measurement of prices and volumes. A more specified universal model can partly solve this problem. However, even a more specified universal model can never serve as the operational model.

The operational model is estimated by combining very heterogeneous and incomplete sets of data (see table 4.1 on the data sources for estimating Dutch GDP via the production approach); the latter include national accounts estimates for previous periods and frames of reference for grossing up and combining data, e.g. a business register or a population census. The major estimation tools are accounting identities, plausibility checks and assumptions.

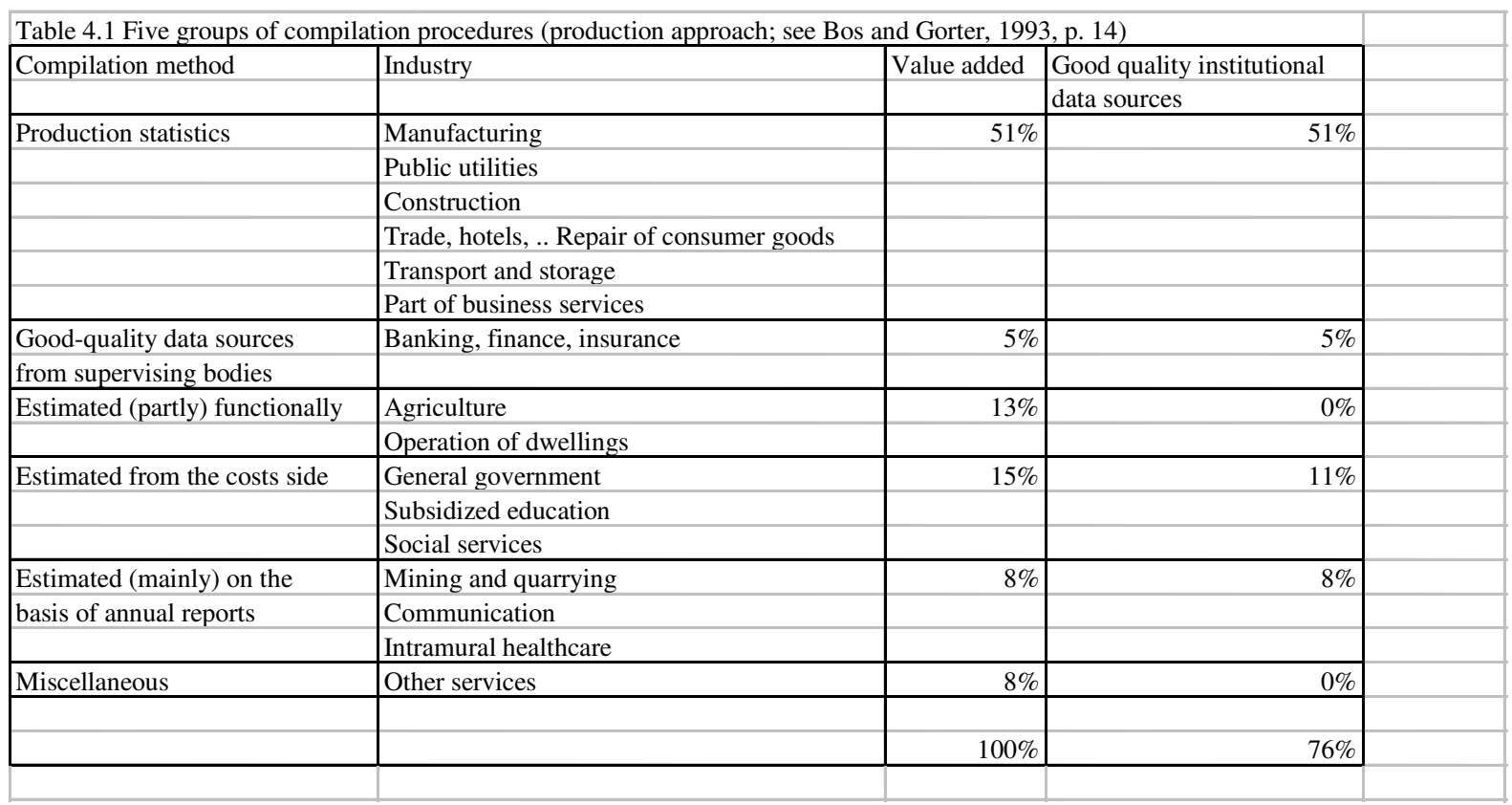

Accounting identities are friends and foes of national accounts statistics. They ensure consistency, can act as plausibility check and allow residual estimates. However, they can also enforce to modify best estimates for the sake of consistency. Furthermore, all residual

8 This section is mainly based on Bos (2007), Bos (2009a, chapters 5 and 7) and Bos (2009b). 
estimates are likely to be very unreliable, as they serve as the garbage bag for errors in all the other estimates.

Plausibility checks are very important for the reliability of national accounts statistics. They can weed out erratic developments in data sources (e.g. due to conceptual changes), can help in detecting all sorts of compilation errors and are important in making estimates during all various stages of the compilation process. Examples of plausibility checks are:

- Check on the plausibility over time of one variable in one data source. For example, detecting erratic developments in output like increases of $20 \%$ and decreases of $30 \%$ in the next year without any clear motivation. Another example is detecting that a major part of the increases in VAT-receipts was not due to increased sales but was caused by accelerated collection.

- Check on the plausibility of the level and development of ratio's between different variables in one data source, e.g. between the volume of labour and the output.

- Check on the plausibility of values and volumes in one data source, e.g. increases of output with $20 \%$ accompanied by decreases of employment with $5 \%$ is generally not very plausible.

- Check on the plausibility by comparing different data sources, e.g. a detailed production statistic are compared with more general information on the developments in one industry, with export statistics on the major product of this industry or with information on wages or employment of that industry.

What is regarded as plausible is ultimately decided by the compilers' skills in inventing plausibility checks, by the compilers' skills in finding plausible answers and by the compilers' personal knowledge and model of the national economy.

Assumptions are essential in combining and completing the basic set of data. Some examples may illustrate the assumptions commonly made:

- The data in the sample (e.g. a survey of households or establishments in construction) or administrative data sources are sufficiently representative for those not included.

- Unchanged composition of a total, e.g. about the commodity breakdown of intermediate consumption by industry or about the breakdown of car registration taxes paid by consumers and by producers (by industry/institutional sector).

- Similar development of a total, e.g. assuming the prices changes observed for some products are relevant for others to or that the average price change observed is a solid approximation of the average price change for the parts not observed. 
- Constancy of a ratio, e.g. between sales and the number of employees of an establishment, between taxes on products and the sales of these products or between income transfers by the government and the compensation of employees and purchases of goods and services financed by these transfers (e.g. income transfers to public schools)

- The change in the volume of government output is equal to the change in the volume of the various costs of production plus a fixed productivity increase of $1 \%$.

The more encompassing, up-to-date, detailed, reliable and conceptually close the basic data set, the smaller the role played by assumptions can be. Plausible assumptions can remedy to a substantial extent the absence of data and are to be preferred to implausible data. However, when for substantial parts of the national economy no plausible data or assumptions are available, national accounts statistics transform into guesswork.

The estimation process is influenced by environmental factors like skills (e.g. skills in combining data and making plausible assumptions), resources (e.g. resources for compiling good price-statistics, for maintaining a reliable business register or for compiling national accounts statistics) and policy (e.g. a mixed strategy of continuity or a preference for prudence and stability).

Official national accounts statistics are generally the only and therefore the best available estimates of the multi-purpose universal model. However, their reliability can differ substantially internationally, over time and even within the same set of national accounts statistics. This is to a great extent the price to be paid for a very ambitious statistic. For example, complete estimates of national economies are to be made, while in all countries for some parts no reliable data (e.g. services industries or illegal production) are available. Furthermore, one universal model is to be estimated even though available data sources, specific circumstances and resources for compiling economic statistics differ widely internationally.

\section{National accounts statistics as a measurement tool}

National economies can not be observed directly, but can only be observed via the national accounts. National accounts statistics make the size, development and composition of these national economies visible by translating them in monetary terms indicating their economic importance. The national accounts are therefore often referred to as the barometer of the national economy. 
However, the national accounts are in many respects a much more complex measuring tool. Unlike a barometer and a thermometer, national accounts statistics are not a mechanical and direct translation of events in the real world.

The universal guidelines of the national accounts are the model underlying national accounts statistics all over the world. For thermometers, there seem to be two competing measurement models, i.e. that of Celsius and Fahrenheit. However, they are identical with the exception of the measuring units, because the temperature indicated by Celsius can be simply translated into those by Fahrenheit and vice versa (an example by Stone, 1951b). This contrasts with the universal national accounting model: this selects what is to be measured and how it is to be measured. Without universal national accounting concepts the national economy is not defined and can thus not be measured. Changes in the universal model also change what is measured by national accounts statistics.

The national accounts are also in several other respects different from a barometer, because it interacts with economic theory, with data sources and administrative concepts, with the real world and with the various uses.

The universal national accounting model is an empirical model. It does not only define what the national economy is, but incorporates also inherent features of current national economies. Put in other words: the universal model is not a random definition of a national economy, but a definition which is selected on being relevant for describing the current national economies. For example, the universal model is in particular designed to describe national economies in which the use of money as a means of exchange, hoarding and accounting plays a dominant role. Similarly, the product-classification in the universal model also reflects the economic importance of the various products in national economies all over the world. As a consequence, important economic and institutional changes can also necessitate changes in the universal model, e.g. the rapidly growing economic importance of new financial derivatives induced their explicit treatment in the new universal model.

The universal national accounting model can also influence the real world and the available data sources. This occurs e.g. when government policy is formulated in terms of national accounting concepts or when the business accounts or government accounts in a country are (partly) based on the universal model of the national accounts. Similarly, economic theory may also be affected by national accounts statistics and their concepts, e.g. Keynesian analysis and growth theory were stimulated by the presence of national accounts statistics. 
Measurement practice consists of a conceptual part, i.e. the formulation of the operational model, and the actual measurement, i.e. the compilation process. The operational model is formulated on the basis of the universal model, the data sources available and the national skills, resources, policies and demands. The compilation process is the result of measuring the national operational model by applying national skills, resources and policies to the data available nationally.

National accounts statistics are a-typical statistics in purpose and method. No other statistic intends to provide a complete picture of the national economy. To this end, national accounts statistics use other statistics, administrative data and qualitative information (e.g. developments reported by branch organisations) as inputs. These very heterogeneous, incomplete, inconsistent, partly outdated and frequently changing data are transformed into one complete, consistent and up-to-date picture of a national economy based on many bookkeeping identities. Sampling theory and mathematical statistics play only a minor role in this transformation.

Compiling official national accounts statistics includes also some economic or econometric modelling,e.g:

- Estimating the value of assets like oil resources as the net present value of expected future revenue and expenditure;

- Correcting household consumption expenditure surveys for non-response using regression analysis;

- Estimating net fixed capital stock and fixed capital using the perpetual inventory method, expected economic life times and mathematical functions of depreciation;

- Estimating the value of the services of owner-occupied dwellings using housing stock data, market rents and regression analysis;

- Estimate seasonal corrections using a mathematical model;

- Estimate hedonic prices changes, e.g. the price change of a computer, using a mathematical model.

Like all statistics outside the textbook-world, national accounts statistics are also influenced by the specific conditions and circumstances of production (skills, resources and policies) and by the specific national demand for data. 
The compilation process and the operational model may also influence the available data sources, e.g. when a statistical survey is conducted in order to compile national accounts statistics.

As a measurement tool, national accounts statistics have much more in common with econometric models than with barometers. Both national accounts and econometric models have to bridge the gap between economic theory and economic data. Both national accounts and econometric models have witnessed a period of joint development with economic theory and both have become products quite independent from economic theory. A quote about the history of econometric models may illustrate this:

"In the first half of the twentieth century, the econometricians found themselves carrying out a wide range of tasks: from the precise mathematical formulation of economic theories to the development tasks needed to build an econometric model; from the application of statistical methods in data preparation to the measurement and testing of models. Of necessity, econometricians were deeply involved in the creative development of both mathematical economic theory and statistical theory and techniques ... the changing nature of the econometric enterprise in the 1940s caused a return to the division of labour favoured in the late nineteenth century, with mathematical economists working on theory building and econometricians with statistical work. By the 1950s the founding ideal of econometrics, the union of mathematical and statistical economics into a truly synthetic economics, had collapsed" (Morgan, 1990, p. 264).

Both large national accounting systems and large econometric models have a very substantial risk to become incomprehensible, impossible to manage and very cost-inefficient. In modern times, there are therefore strong demands for simple and small models focused on specific issues. This applies to econometric models as well as to national accounts statistics. The major merit of large national accounting systems and large econometric models is that they provide a general overview in which various issues can be linked. Both large national accounting systems and large econometric models should not be driven to extremes, as one giant model can never efficiently and adequately serve all purposes.

Compiling national accounts statistics and building econometric models have also much in common, as they both depend to a great extent on skills and tacit knowledge. Building econometric models does not amount to simply following the methods 
recommended by text books. According to Bodkin, Klein and Marwah (1991, p. 533): "in the present state of the discipline, macro econometric model-building is at least as much of an art as it is a set of scientific procedures".

This was clearly illustrated by two experiments in the practice of econometrics (Magnus and Morgan, 1998). The first experiment was a field trial experiment: participating teams, with different methodological positions, answer specific economic questions using a given data set. The second experiment was a tacit knowledge experiment: an "apprentice" tries to emulate the approaches of three "master" econometricians on the same applied problem. The two experiments confirmed the findings other experimental studies of practice and tacit knowledge. Applying econometric methodologies involves a large element of choice and judgement decisions which rely on tacit knowledge rather than on rule following.

Tacit knowledge plays also an important role in the national accounts' practice. Tacit knowledge is important in defining the operational model and in compiling national accounts statistics. The national accounts' practices also differ substantially among countries and change over time, e.g. because compilers move to other jobs or because new tools and data become available. Experiments in the national accounting practice may also clarify the role of tacit knowledge in national accounts statistics. For example, ask different teams (from various countries, but also from the same national accounts department) to compile national accounts statistics on the basis of a specific data set.

Also the process of defining and agreeing on the universal model will reflect to a substantial extent tacit knowledge of the persons involved. A major merit of the universal guidelines is that much personal knowledge is translated into publicly available information.

Large econometric models used for the official forecasts or analyses of the government are part of a political decision-making process in which policy makers and empirical modellers interact (see Den Butter and Morgan, 1998). The quality of forecasts in such a context depends not only on purely statistical criteria. This is illustrated by a quote from the Director of the Dutch CPB:

"Statistical criteria for forecast quality in practice have limited relevance. Three nonstatistical criteria for forecast quality are put forward: logical coherence, economic coherence and stability. ... a forecaster must enable his client to form his opinion on the uncertainty associated with the forecast. To this end, uncertainty variants and alternative scenarios appear adequate.” (Don, 2001, p. 155). 
National accounts statistics are also part of a political decision-making process ${ }^{9}$. As a consequence, non-statistical criteria of quality, like stability, economic coherence and reputation, are also very important for national accounts statistics.

These non-statistical criteria also reflect technical features of the national accounts, like the overall complexity of national accounts statistics and the non-sampling features of many data sources. Balancing the national accounts in view of all available information is many respects similar to the calibration of an econometric model on the basis of stylised facts 10 . Like for large econometric models, the reliability of national accounts statistics should not only be investigated by purely statistical methods but also by conducting sensitivity analysis like the uncertainty variants and alternative scenarios.

\footnotetext{
${ }^{9}$ Econometric models, national accounts and their relationships with politics and society can also be viewed from a wider perspective, i.e. as part of the role of quantification in politics and society. There is a whole literature on this, see e.g. Alonso and Starr (1987).

10 On calibration of economic and econometric models, see Boumans (2001).
} 


\section{References}

Alsonso, W. and P. Starr (eds.), 1987, The Politics of Numbers (Russell Sage Foundation, New York).

Bodkin, R.G., L.R. Klein and K. Marwah, 1991, A History of Macroeconometric ModelBuilding (Edward Elgar, Aldershot).

Bos, F., 1993, Standard national accounting concepts, economic theory and data compilation issues; on constancy and change in the United Nations-manuals on national accounting (1947, 1953, 1968 and 1993), National Accounts Occasional Paper 61 ( Statistics Netherlands, Voorburg).

Bos, F., 1995, National accounting and economic theory, National Accounts Occasional Paper 75 (Statistics Netherlands, Voorburg).

Bos, F., 1997, Value and Income in the National Accounts and Economic Theory, Review of Income and Wealth, vol. 43, pp. 173-190.

Bos, F., 2007, Compiling the national accounts demystified, National Accounts Occasional Papers nr 95 (Statistics Netherlands, Voorburg).

Bos, F., 2008, Uses of National Accounts: History, International Standardization and Applications in the Netherlands, Eagle Economics and Statistics Working Paper nr 1, MPRA paper 9387

Bos, F., 2009a, The National Accounts as a Tool for Analysis and Policy; in View of History,

Economic Theory and Data Compilation Issues (VDM Verlag Dr. Muller, Saarbrücken).

Bos, F., 2009b, The Art and Craft of Compiling National Accounts Statistics and their Implications for Reliability, Review of Income and Wealth, Vol. 55, Issue 4, pp. 930958.

Bos, F., 2011, Three Centuries of Macro-Economic Statistics, MPRA paper nr. 35391.

Bos, F. and C.N. Gorter (eds.), 1993, Compiling Dutch Gross National Product (GNP); Full Report on the Final Estimates After the Revision in 1992. National Accounts Occasional Paper nr. 57-extended (Statistics Netherlands, Voorburg).

Boumans, M., 2001, Measure for Measure: How Economists Model the World into Numbers. Social Research, Vol. 68, No. 2, pp. 427-453.

Don, F.J.H., 2001, Forecasting in Macroeconomics: a Practitioner's View. De Economist, pp. 155-175. 
Kendrick, J.W. (ed.), 1995, The New System of National Accounts (Kluwer, Boston/Dordrecht/London).

Kenessey, Z (ed.), 1994, The Accounts of Nations (IOS Press, Amsterdam).

Maddison, A., 2005, Measuring and interpreting world economic performance 1500-2001, Review of Income and Wealth, 1-36.

Magnus, J.R. and M.S. Morgan, 1999, Methodology and Tacit Knowledge; Two Experiments in Econometrics (John Wiley \& Sons, New York).

Mankiw, N.G., 2006, The Macroeconomist as Scientist and Engineer, Journal of Economic Perspectives, vol. 20, nr. 4, 29-46.

Morgan, M., 1990, The History of Econometric Ideas. (Cambridge University Press, Cambridge).

Ruggles, R., 1990, A note on the revision of the United Nations System of National Accounts, Review of Income and Wealth, 36(4), pp. 413-419.

Schumpeter, J.A., 1945, History of Economic Analysis (Allen \& Unwin, London).

Stone, R., 1947, Definition and Measurement of the National Income and Related Totals. Appendix in UN (1947).

Stone, R., 1951b, The Role of Measurement in Economics, The New March Lectures 19481949 (Cambridge University Press).

Stone, R., 1997, Some British Empiricists in the Social Sciences 1650-1900 (Cambridge University Press, Cambridge)

Studenski, P., 1958, The Income of Nations. (New York University Press, New York).

Vanoli, A., 2005, A History of National Accounting (IOS Press, Amsterdam). 